\title{
Epileptic Seizures in Critically Ill Patients: Diagnosis, Management, and Outcomes
}

\author{
Mathilde Holleville ${ }^{1,2}$, Gwenaëlle Jacq ${ }^{2,3}$, François Perier ${ }^{2,4}$, Candice Fontaine ${ }^{2,5}$ \\ and Stephane Legriel $2,3,6, *$
}

1 Department of Anaesthesiology and Critical Care, Hôpitaux Universitaires Paris Nord Val de Seine, Hôpital Beaujon, 100 Boulevard du Général Leclerc, 92110 Clichy, France; mathildeholleville@gmail.com

2 IctalGroup, 78150 Le Chesnay, France; gjacq@ch-versailles.fr (G.J.); francoisperier@hotmail.fr (F.P.); candicefontaine@yahoo.com (C.F.)

3 Intensive Care Department, Centre Hospitalier de Versailles, 177 rue de Versailles, 78150 Le Chesnay CEDEX, France

4 Medical Intensive Care Unit, Assistance Publique-Hôpitaux de Paris, CHU Henri Mondor, 51 Avenue du Maréchal de Lattre de Tassigny, 94010 Créteil, France

5 Medical-Surgical Intensive Care Unit, Hopital Paris Saint Joseph, 185 Rue Raymond Losserand, 75014 Paris, France

6 UVSQ, INSERM, University Paris-Saclay, CESP, Team « PsyDev », 94800 Villejuif, France

* Correspondence: stlegriel@gmail.com or slegriel@ch-versailles.fr; Tel.: +33-139-638-839; Fax: +33-139-638-688

Received: 5 July 2020; Accepted: 10 July 2020; Published: 13 July 2020

\begin{abstract}
Epileptic seizures in critically ill patients represent a major source of concern, because they are associated with significant mortality and morbidity rates. Despite recent advances that have enabled a better understanding of the global epidemiology of this entity, epileptic seizures in critically ill patients remain associated with a high degree of uncertainty and numerous questions remain unanswered. The present Special Issue aims to invite authors to contribute original research articles as well as review articles related to all aspects of epileptic seizures in critically ill patients, diagnosis, management, and outcomes.
\end{abstract}

Keywords: seizures; status epilepticus; critically ill; electroencephalography; adults; children

Epileptic seizures in critically ill patients represent a major source of concern, because they are associated with significant mortality and morbidity rates [1]. Seizures may be convulsive or nonconvulsive. They may also be prolonged in duration reaching the diagnosis criteria for status epilepticus. They can occur in various settings, and can involve a large spectrum of multidisciplinary teams, including but not limited to medical physicians and nurses from emergency departments, operating rooms, or intensive and neurocritical care units.

Recent advances have enabled a better understanding of the global epidemiology of this entity [2-4]. The greater implementation of continuous EEG monitoring has certainly contributed to this $[5,6]$. Seizures diagnostic relies on having good knowledge of the different electro-clinical presentations, themselves illustrated by the recent update in the classifications of seizures and status epilepticus [7,8]. Management of seizures associates general measures with organ failure supportive care, according to patient's severity, antiepileptic treatment appropriate for the electrical and clinical pattern in the patient, investigations for a cause and etiological treatment, and electroencephalography monitoring [9].

However, epileptic seizures in critically ill patients remain associated with a high degree of uncertainty, and numerous questions remain unanswered [10]. Indeed, further progress is necessary regarding diagnostic procedures to better identify situations in which electroencephalogram should be performed in emergency situations. While the contribution of continuous electroencephalographic 
monitoring is intuitively obvious, we should also progress in demonstrating its superiority when compared to the sequential approach [11]. Additional questions should be addressed, like who must do it [12-14], with which equipment and technics types [15,16], using which electroencephalographic montages [17], for how long, within which emergency time frame [14], and ultimately for which specific patient population [18]?

Beyond the unspecific management description, we do not really know who to treat and when to treat them with regard to epileptic seizures in critically ill patients, nor what the most efficient treatments are [19-21]. The role of general anesthesia and which agents should be used remains debated, just like the place of adjuvant anticonvulsant and neuroprotective strategies [22-24]. Furthermore, additional progress needs to be made to define the roles and interactions between the protagonists involved in the management of these patients: nurses, emergency physicians, intensivists, neurointensivists, neurologists, and neurophysiologists $[25,26]$.

Finally, few data are available regarding the large spectrum of presentation, the underlying conditions, the immediate severity, and their association with outcomes in critically ill patients with epileptic seizures in each of the various settings cited above.

The present Special Issue invites authors to contribute original research articles, as well as review articles related to all aspects of epileptic seizures in critically ill patients, diagnosis, management, and outcomes.

Author Contributions: Drafting of the first version of the manuscript: S.L.; Critical revision of the manuscript for important intellectual content: S.L., C.F., G.J., M.H., F.P. All authors have read and agreed to the published version of the manuscript.

Funding: This research received no external funding.

Conflicts of Interest: The authors declare no conflict of interest.

\section{References}

1. Strein, M.; Holton-Burke, J.P.; Smith, L.R.; Brophy, G.M. Prevention, treatment, and monitoring of seizures in the intensive care unit. J. Clin. Med. 2019, 8, 1177. [CrossRef] [PubMed]

2. Jirsch, J.; Hirsch, L.J. Nonconvulsive seizures: Developing a rational approach to the diagnosis and management in the critically ill population. Clin. Neurophysiol. 2007, 118, 1660-1670. [CrossRef]

3. Alvarez, V.; Westover, M.B.; Drislane, F.W.; Dworetzky, B.A.; Curley, D.; Lee, J.W.; Rossetti, A.O. Evaluation of a clinical tool for early etiology identification in status epilepticus. Epilepsia 2014, 55, 2059-2068. [CrossRef] [PubMed]

4. Struck, A.F.; Tabaeizadeh, M.; Schmitt, S.E.; Ruiz, A.R.; Swisher, C.B.; Subramaniam, T.; Hernandez, C.; Kaleem, S.; Haider, H.A.; Cisse, A.F.; et al. Assessment of the validity of the 2HELPS2B score for inpatient seizure risk prediction. JAMA Neurol. 2020, 77, 500-507. [CrossRef]

5. Claassen, J.; Mayer, S.A.; Kowalski, R.G.; Emerson, R.G.; Hirsch, L.J. Detection of electrographic seizures with continuous EEG monitoring in critically ill patients. Neurology 2004, 62, 1743-1748. [CrossRef] [PubMed]

6. Jette, N.; Claassen, J.; Emerson, R.G.; Hirsch, L.J. Frequency and predictors of nonconvulsive seizures during continuous electroencephalographic monitoring in critically ill children. Arch. Neurol. 2006, 63, 1750-1755. [CrossRef]

7. Fisher, R.S.; Cross, J.H.; French, J.A.; Higurashi, N.; Hirsch, E.; Jansen, F.E.; Lagae, L.; Moshe, S.L.; Peltola, J.; Perez, E.R.; et al. Operational classification of seizure types by the International League Against Epilepsy: Position paper of the ILAE commission for classification and terminology. Epilepsia 2017, 58, 522-530. [CrossRef]

8. Trinka, E.; Cock, H.; Hesdorffer, D.; Rossetti, A.O.; Scheffer, I.E.; Shinnar, S.; Shorvon, S.; Lowenstein, D.H. A definition and classification of status epilepticus-Report of the ILAE task force on classification of status epilepticus. Epilepsia 2015, 56, 1515-1523. [CrossRef]

9. Brophy, G.M.; Bell, R.; Claassen, J.; Alldredge, B.; Bleck, T.P.; Glauser, T.; Laroche, S.M.; Riviello, J.J., Jr.; Shutter, L.; Sperling, M.R.; et al. Guidelines for the evaluation and management of status epilepticus. Neurocrit. Care 2012, 17, 3-23. [CrossRef] 
10. Sutter, R. Are we prepared to detect subtle and nonconvulsive status epilepticus in critically ill patients? J. Clin. Neurophysiol. 2016, 33, 25-31. [CrossRef]

11. Eskioglou, E.; Stahli, C.; Rossetti, A.O.; Novy, J. Extended EEG and non-convulsive status epilepticus: Benefit over routine EEG? Acta Neurol. Scand. 2017, 136, 272-276. [CrossRef] [PubMed]

12. Legriel, S.; Jacq, G.; Lalloz, A.; Geri, G.; Mahaux, P.; Bruel, C.; Brochon, S.; Zuber, B.; Andre, C.; Dervin, K.; et al. Teaching important basic EEG patterns of bedside electroencephalography to critical care staffs: A prospective multicenter study. Neurocrit. Care 2020. [CrossRef] [PubMed]

13. Vespa, P.M.; Olson, D.M.; John, S.; Hobbs, K.S.; Gururangan, K.; Nie, K.; Desai, M.J.; Markert, M.; Parvizi, J.; Bleck, T.P.; et al. Evaluating the clinical impact of rapid response electroencephalography: The DECIDE multicenter prospective observational clinical study. Crit. Care Med. 2020. [CrossRef] [PubMed]

14. Yazbeck, M.; Sra, P.; Parvizi, J. Rapid response electroencephalography for urgent evaluation of patients in community hospital intensive care practice. J. Neurosci. Nurs. 2019, 51, 308-312. [CrossRef]

15. Stewart, C.P.; Otsubo, H.; Ochi, A.; Sharma, R.; Hutchison, J.S.; Hahn, C.D. Seizure identification in the ICU using quantitative EEG displays. Neurology 2010, 75, 1501-1508. [CrossRef]

16. Hobbs, K.; Krishnamohan, P.; Legault, C.; Goodman, S.; Parvizi, J.; Gururangan, K.; Mlynash, M. Rapid bedside evaluation of seizures in the ICU by listening to the sound of brainwaves: A prospective observational clinical trial of ceribell's brain stethoscope function. Neurocrit. Care 2018, 29, 302-312. [CrossRef]

17. Westover, M.B.; Gururangan, K.; Markert, M.S.; Blond, B.N.; Lai, S.; Benard, S.; Bickel, S.; Hirsch, L.J.; Parvizi, J. Diagnostic value of electroencephalography with ten electrodes in critically ill patients. Neurocrit. Care 2020. [CrossRef]

18. Struck, A.F.; Osman, G.; Rampal, N.; Biswal, S.; Legros, B.; Hirsch, L.J.; Westover, M.B.; Gaspard, N. Time-dependent risk of seizures in critically ill patients on continuous electroencephalogram. Ann. Neurol. 2017, 82, 177-185. [CrossRef]

19. Nau, K.M.; Divertie, G.D.; Valentino, A.K.; Freeman, W.D. Safety and efficacy of levetiracetam for critically ill patients with seizures. Neurocrit. Care 2009, 11, 34-37. [CrossRef]

20. Parkerson, K.A.; Reinsberger, C.; Chou, S.H.; Dworetzky, B.A.; Lee, J.W. Lacosamide in the treatment of acute recurrent seizures and periodic epileptiform patterns in critically ill patients. Epilepsy Behav. 2011, 20, 48-51. [CrossRef]

21. Perrenoud, M.; Andre, P.; Alvarez, V.; Stahli, C.; Decosterd, L.A.; Rossetti, A.O.; Novy, J. Intravenous lacosamide in status epilepticus: Correlation between loading dose, serum levels, and clinical response. Epilepsy Res. 2017, 135, 38-42. [CrossRef] [PubMed]

22. Legriel, S. Hypothermia as a treatment in status epilepticus: A narrative review. Epilepsy Behav. 2019, 101, 106298. [CrossRef] [PubMed]

23. Legriel, S. Hypothermia as an adjuvant treatment in paediatric refractory or super-refractory status epilepticus. Dev. Med. Child Neurol. 2020. [CrossRef] [PubMed]

24. Legriel, S.; Lemiale, V.; Schenck, M.; Chelly, J.; Laurent, V.; Daviaud, F.; Srairi, M.; Hamdi, A.; Geri, G.; Rossignol, T.; et al. Hypothermia for neuroprotection in convulsive status epilepticus. N. Engl. J. Med. 2016, 375, 2457-2467. [CrossRef] [PubMed]

25. Barry, K.; Teixeira, S. The role of the nurse in the diagnostic classification and management of epileptic seizures. J. Neurosurg. Nurs. 1983, 15, 243-249. [CrossRef] [PubMed]

26. Kaplan, P.W. Nonconvulsive status epilepticus in the emergency room. Epilepsia 1996, 37, 643-650. [CrossRef]

(C) 2020 by the authors. Licensee MDPI, Basel, Switzerland. This article is an open access article distributed under the terms and conditions of the Creative Commons Attribution (CC BY) license (http://creativecommons.org/licenses/by/4.0/). 